\title{
香港の上級日本語学習者が書いた「依頼」のメールの評価 \\ 一日本語教師ではない読み手の視点一 \\ A study of the assessment of request E-mails written by Hong Kong-based advanced Japanese language learners from the perspective of readers \\ who are not Japanese language teachers
}

\section{上田 早苗 \\ 香港中文大学}

\section{要旨}

筆者は、作文の授業でメール文の書き方を教えているが、その評価の際には、 教師よりむしろ実際に受け取って読む立場の人がどのように感じるかが重要では ないかと思う。本稿では、香港の上級日本語学習者が書いた「ホストファミリー宛て の依頼のメール」を、日本語教育経験のない日本語母語話者 3 名に読んでもらい、 よいと思う順に順位を付けてもらった上で、評価の観点や理由についてコメント してもらった。そして、日本語教師であり日本語母語話者である筆者が付けた順位を 含めて結果を比較し、考察を行った。その結果、次のことがわかった。(1)「前置き $\rightarrow$ 本題 $\rightarrow$ 結び」という構成で、読み手に対する気づかいを感じさせる言葉や読み手 にとって必要な情報を過不足なく含み、日本語としての正確さもあるメール文に 対して、日本語母語話者は高い評価を与える。(2)情報量が非常に多い場合は、大きく 評価が分かれる。(3)日本語の正確さには欠けるが、読み手に対する気づかいを感じ させる言葉を含んでいる場合、大きく評価が分かれる。

キーワード :

香港の上級日本語学習者、「依頼」のメール、評価、日本語教師ではない読夕手 


\section{香港の上級日本語学習者が書いた「依頼」のメールの評価 \\ 一日本語教師ではない読み手の視点一}

\section{上田 早苗 香港中文大学}

\section{1.はじめに}

由井 (2005：187) は、「話すのが上級になった学習者でも、簡単なメモ 1 つって みても十分に書けているとは限らない。文法や語彙上の変な間違いがあったり、 何か失礼な印象を受けるような文であったりすることは多くの日本語教師が経験 していることであろう。」と述べている。筆者は、「上級日本語作文」のコースの一部 として、学習者が現在または将来、日常生活の中で書く機会があるであろうメール 文を取り入れてきた。その際、読み手の立場に立って考えながら書くように指導 してきた。日本語教師は、「作文」の授業で学習者が書いたものを添削し、成績を 付けることになる。筆者は、アメリカ外国語教育協会 (ACTFL) の「ACTFL ライティング の評価基準」1などの基準を参考にしつつ、学習者の書いたものを評価している。 しかし、例えばメール文のような実用文の場合は、教師よりはむしろそれを実際に 受け取って読む立場の人がどのように感じるかが重要なのではないだろうか。 そもそも、教師の視点と実際の読み手の視点は一致しているのだろらか。

そこで、今回、香港の上級日本語学習者が書いた「ホストファミリー宛ての依頼 のメール」を、日本語教育経験のない日本語母語話者 3 名に読んでもらい、よい と思う順に順位を付けてもらった上で、評価の観点や理由についてコメントして もらった。本稿では、日本語母語話者であり日本語教師でもある筆者が付けた 順位を含めて結果を比較し、考察したい。

\section{2. 先行研究}

上田（2017）は、学習者が作成した「依頼」のメール文を、展開要素に着目して 調査し、どのような問題が見られるのか考察している。しかし、日本語教師ではない 読み手の観点については言及されていない。また、外国人が書いた日本語手紙文に 対する日本語母語話者の評価に関する研究として、宇佐美・森・吉田（2009）がある。 宇佐美・森・吉田（2009：123）は、「一般日本人」を一つのグループと考え、外国 人が書いた日本語手紙文を「日本人（教師も一般日本人も含む）が評価する際、

1 The American Council on the Teaching of Foreign Languages(2012) $「$ ACTFL PROFICIENCY GUIDELINES 2012」

$<$ https://www.actfl.org/publications/guidelines-and-manuals/actfl-proficiency-guidelines-2012/japanese /\%E3\%83\%A9\%E3\%82\%A4\%E3\%83\%86\%E3\%82\%A3\%E3\%83\%B3\%E3\%82\%B0>

(2017 年 11 月 26 日閲覧) 


\section{香港の上級日本語学習者が書いた「依頼」のメールの評価}

一日本語教師ではない読み手の視点一

どのような観点を用い、どのような過程を経ているかということ」を分析し、 個人の価值観のあり方を明らかにすることを試みている。宇佐美・森・吉田 (2009) の研究は「外国人に対する日本語教育というより、むしろ日本人に対するコミュニ ケーション教育に必要なことである」と述べられており、本研究とは目的が異なるが、 外国人が日本語母語話者に向けて何らかのコミュニケーションをとるために書いた 文を日本語母語話者が評価するという点を参考にした。

確かに、個人によって評価のばらつきが出るのは仕方がないとしても、もし多くの 日本人が「よい」と感じるメール文の特徵や傾向があるならば、それはどのような ものか、少なくとも学習者は情報として知っておいたほうがよいのではないかと 筆者は考える。そこで、本稿では、「日本語教師ではない日本人」がどのような理由 でどのように順位を付けるのかを調査する。そして、評価にどれぐらいばらつきが 出るのか、さらに、日本語教師である筆者がよいと思うメール文を「日本語教師 ではない日本人」もよいと思っているのかについても見てみたい。

\section{3. 調查方法}

\section{1 評価の対象となるメール文}

評価の対象となるのは、香港の大学で「上級日本語作文」（2010-2011 年度〜 2015-2016 年度）を履修した学習者（計 75 名））がコース中の課題として書いた メール文から選んだ 5 編である。履修者は、大部分が日本研究を専攻とし、3 年次に 1 年間の日本留学経験がある最終学年の学生である 2 。非専攻生の学生も希望すれば 履修できるが、N2 合格以上が履修条件となる。また、履修者は、香港出身の広東語 母語話者である3 ${ }^{3}$ 。対象となる課題は以下のとおりである。

友達と冬休みに日本へ旅行に行くことになりました。友達は日本人のうちを 見たことがないと言っています。留学中にお世話になったホストファミリーの お母さんに事情を話して、一晚泊めてもらえるようにお願いしてください。 必要な情報は補って構いません的。

評価の対象となる 5 編のメール文を選ぶ際には、コースの担当教員である筆者の 目から見て、このコースの履修者全体の中で上位、中位、下位（コース履修当時の レベル）の学習者が含まれるようにした。対象となるメール文だけではなく、

24 年制に移行する前の 3 年制の時には 2 年次に 1 年間、日本留学していた。

3 数名の北京語母語話者と英語母語話者の履修者がいたが、対象となるメール文執筆者の母語の 条件をそろえるため、広東語母語話者のみを調査対象とした。

4 箈・大木・小松（2005：47）及び野田・森口（2003）を参考にして筆者が課題文を作成した。 
コースの中で学習者が書いたさまざまなメール文や意見文など他の課題の出来も 総合的に見た上で、筆者が書く力が上位であると考える学習者 1 名 (学習者 A)、 中位であると考える学習者 2 名(学習者 C、D)、下位であると考える学習者 2 名 (学習者 $\mathrm{E} 、 \mathrm{~B})$ が書いた「依頼」のメール文を選択した。参考までに、筆者が考える 書く力の総合順位は高い方から「 $「 \mathrm{~A} \rightarrow \mathrm{C} \rightarrow \mathrm{D} \rightarrow \mathrm{E} \rightarrow \mathrm{B}\rfloor$ あ゙あ。さらに、対象となる メール文についての、筆者自身が考える順位も付けておいた。それについては、

4. で述べる。

\section{2 評価データの収集方法}

\section{2.1 評価者}

上記のように選んだ 5 編を、日本語教育経験のない 3 名の日本人（以下、NT1、NT2、 NT3 とする）に読んでもらった。NT1、NT2、NT3 は全員、日本国内在住である。 外国人をホストファミリーとして受け入れたことはないが、それぞれ小学生から 高校生までの子供がいて、3 名とも自身の子供を海外または日本国内でホーム ステイさせた経験があり、国際交流に興味がある。将来的にこのようなメール文を 受け取る立場となる可能性があるということで今回の調查協力をお願いした。 評価者の属性を表 1 に示す。

\section{表 1}

\begin{tabular}{|c|c|c|c|c|c|}
\hline 評価者 & 性別 & 年歯令 & 居住地 & 母語 & 日本語教育歴 \\
\hline NT1 & 女性 & 40 代 & 奈良県 & 日本語 & なし \\
\hline NT2 & 女性 & 50 代 & 大阪府 & 日本語 & なし \\
\hline NT3 & 女性 & 40 代 & 奈良県 & 日本語 & なし \\
\hline
\end{tabular}

筆者は授業を通して評価対象となるメール文を作成した学習者を知っているが、 評価者はメール文を書いた学習者と面識がない。

\section{2.2 順位付けとコメント}

2017 年 7 月に、日本国内で、NT1、NT2、NT3 に個別に会ってインタビューを 行った。インタビューは、各評価者の許可を得て録音した。 3 名の評価者には、 学習者 A〜E が書いたメール文を読んでもらい、よいと思う順に順位を付けてもらった 上で、それぞれ評価の観点や理由について自由にコメントしてもらった。メール文 $\mathrm{A} \sim \mathrm{E}$ の順番は、筆者があらかじめ付けた順位とは関係なくアトランダムになって おり、筆者が考える順位は評価者には知らせなかった。

\section{4. 順位付けの結果}

学習者 A〜E が書いたメール文に対して、筆者と NT1、NT2、NT3 が付けた順位を 表 2 に示す。 
表 2 筆者と NT が付けた順位（最もよいものが 1 位）

\begin{tabular}{|c|c|c|c|c|c|}
\hline & 1 位 & 2 位 & 3 位 & 4 位 & 5 位 \\
\hline 筆者 & D & A & C & E & B \\
\hline NT1 & A & C & E & B & D \\
\hline NT2 & D & C & A & E & B \\
\hline NT3 & B $/ A$ & - & C & D & E \\
\hline
\end{tabular}

なお、NT3 は B とAについて「タイプは違うが同率一位」であると言ったので、 2 編のメール文が同じ順位となっている。

\section{5. 各メール文に対するコメント ${ }^{5}$}

\section{1 評価のばらつき}

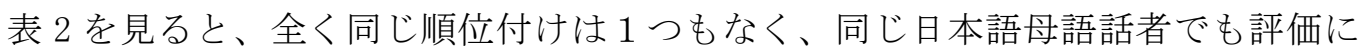
ばらつきが出ていることは宇佐美・森・吉田（2009）の指摘どおりである。しかし、 $\mathrm{A}$ は上位（ 1 位〜 3 位)、C は中位（2 位〜 3 位）、E は下位（3 位〜 5 位）というよう に、A、B、E に関しては、筆者を含む 4 名の母語話者の評価はばらつきが少ないと 言える。一方、B と D に関しては、どちらも 1 位または 4 位〜 5 位となっており、 上位か下位に大きく評価が分かれている。この原因を探るために、各メール文に 対する評価者のコメントを詳しく見ていきたい。

\section{2 評価が上位の学習者 $A$ のメール文}

学習者 Aのメール文に 1 位を付けたのは、NT1 と NT3 である。NT2 は 3 位を付けて いる。

(1)NT1のAに対するコメント

・すごく内容が普通。こう、自分の近況を言って、で、そちらがすごくよかった っていうことと、それから友達を連れていくという時に「ご迷惑でなければ、 私と友達を泊めていただけないでしょうか」っていう聞き方も、普通だし。

・ところどころ文法的におかしいなとは思うけど、ま、外国人の方が書いたと しては、「一生忘れることができない素敵な経験だったので」とか、泊める側 としたらそう言ってもらえたら、あ、泊めてあげようかなという気にもなる。 ・旅行する期間をはっきり、「12 月末の 1 週間を予定していますが、その中の 一晚泊めていただければ」っていうことやから、こっちも予定が立てやすいし。 で、「お返事お待ちしております」っていうような、すごく流れのいい、感じ のいい内容。一番よかったなって。

5 評価者の発言は、録音されたデータに忠実に方言もそのままにしてある。 
(2) N3 の A に対するコメント

・完璧な日本語で、完璧に日本人の礼儀作法もわかっていて、日本人の心を わしづかみにするような感じ。

・この子は何でもできて、完璧な子ですごい子なんだから泊めてあげても全然 問題はなさそう。

・すごい優等生なんだろうなと思って。

・非の打ちどころのないのは $\mathrm{A}$ 。

(3)NT2 のA に対するコメント

・C と A は日本語もわりとよく、それほど大差が感じられない。

・やっぱり標題が「宿泊について」とかだと、ほかの宿泊の自分が泊まったとこ かしら、と思ってしまう。

\section{3 評価が中位以上の学習者 Cのメール文}

NT1 と NT2 は、学習者C のメール文に 2 位を付けている。一方、NT3 は 3 位を 付けている。

(4)NT1のCに対するコメント

・すごくシンプル。で、なんやかんや書いてないけども、いつからいつまで 冬休みで友達と遊びに行くと。で、「友達はホームステイしたことないから、 泊めてもらえないか」っていう、ま、メールとしては読みやすいし、で、内容 もはっきり、言いたいこともわかるし。で、「日本人のおうちを見たことが ないから、泊めていただけないか」っていうことが、すごく丁寧ではないけど、 わかりやすい。

(5) NT2 のCに対するコメント

・C と A は日本語もわりとよく、それほど大差が感じられない。

・最後に、Eメールのアドレスが載っていて返信しやすい。で、「香港からの〜 です」っていうタイトルで、ほかのスパムメールとは違って、あ、彼女から 来たんだわ、ということがわかりやすくて、メールを開きやすい点が C の レベルが上の点でしょうか。

(6) N3 のCに対するコメント

・自分のちゃんと近況報告もして、一番これが平均的な感じ。

・ただ、何ていうか、こっちの都合、聞いてないけど、「もしだめならいいです」 って言うのがあれば。都合を聞いてもらえれば（いい）。

・どうして行きたいかとか、どうしてその子、泊まりたいかっていうのも 「ホームステイしたことないから、見たいらしいから、どうかな」、みたいな 感じで。ま、「可能でしたら」って聞いてくれてるからいいねんけど、ほんとに これはもう、普通の。一般的な、平均的な、もう本に書いてあるやん、ひな形 通りの。 


\section{香港の上級日本語学習者が書いた「依頼」のメールの評価}

\section{4 評価が下位の学習者 $\mathrm{E}$ のメール文}

学習者 Eのメール文に対して、NT1 は 3 位、NT2 は 4 位、NT3 は 5 位を付けている。

(7)NT1のEに対するコメント

・文章短くて、わかりやすいし、ま、ちょっと丁寧さには欠けるかなとは思う けど、メールとしたら、あの、やっぱり「友達と一緒に行くから泊めてもらえ ませんか」で、ちょっと期間が書いてないのが、わかりにくいけども、ま、 「いいよー、いつ?」って返事を書くには、まあ、これぐらいでいいのと、で、 「返事は 11 月 20 日までにください」っていう、は、ちゃんと書いてあるので、 メールとしては、言いたいことがわかる。

(8)NT2のEに対するコメント

・(C、A と比べても) ほとんど落ちない。何が違うんだろうって思ったときに、 ここもちやんと期限も書いてあるし、人も書いてあるし、特にこの 3 つ ( C、A、E) に関して、これが秀逸だと思うところはないです。

・言葉の使い方で言うと、一番簡単に済まされているような気がして、CとAの ほうが丁寧さを感じる点が…。でも、特に E がどっかがおかしいから意味が 伝わらないっていうことはほとんどないので...。

・Eの人は、突然その、泊めてもらいたい理由とかに入っているので、そう いったちょっとした季節のこととか、さりげない、「自分はこんなことが好き になった」とかいうことが書かれていると、よりコミュニケーションがとり やすいということはあるかなあと思います。

(9) N3 の E に対するコメント

・多分、日本語が下手で、すごい日本語の訳し方って言うのかな、こっちも 英語が下手で英語の例文集をつなぎ合わせて書いてるっていう。よくやる やん、できひん時、英作文書く時。

・自分の魂から出ている言葉がない。ひな形通りで、たぶん辞書で引いて、ああ こういうことがあるからここだけ書いて、自分がよくやるタイプやねんけどね。

・でも一応知り合いやし、情報を送るとか、こっちのことを気づからとか、 もあってもいいと思うねんな。でも、これってほんとに多分、こういう子じや ないと思うねんけど。

・(件名の)「泊めるに関するお願い」っていうのが、もうちょっと「お元気です か」とか。

・呼び方は「お母さん」のほうが絶対（いい）。お母さんやと思って世話してん ねんから。 


\section{5 評価に著しくばらつきがある学習者 D のメール文}

\subsubsection{D を上位とした評価者のコメント}

学習者 D が書いたメール文に 1 位を付けたのは、NT2 である。

(10)NT2 の D に対するコメント

・文章が長いということもありますが、お母さんのことを気づかっていて親しみ が持てる。

・泊まりたい理由、泊まりたい日程などもはっきり書いてあるので判断がし やすい。

・きっちり 19 日か 20 日で友達が一人来て、断ってもらっても全然大丈夫と 書かれているので、一番わかりやすかった。

\subsubsection{D を下位とした評価者のコメント}

学習者Dのメール文に対して、NT1 とNT3 はそれぞれ 5 位と 4 位を付けている。

(11)NT1のD に対するコメント

・いろいろ書いてて、手紙としたらいいんやけど、メールとしたら、ああだこうだ 書いて、長すぎる。

・私がこれを最後にしたポイントは、「ついでにその友達は日本人の家を見た ことがなくてぜひ体験したいと言っていましたから」って言うね。「もう一度 会いたいです、なので、おうちに泊めていただけませんか。その時に友達も 一緒に。」って言うんやったらいいけど、「ついでに」っていうところがちょっと。 こっちとしたらちょっと負担やから、友達を一緒に泊めるって言うのが。 やっぱり、そこの表現が、大目に見てもトゲ刺さっちやうみたいな。

(12）N3 のD に対するコメント

・キャラが濃い感じで、詰め込めるだけ詰め込んで。ま、こういう子なんやろう けど、お土産を先に送ってきてるから、断りづらいって言うか。これは日本人 にしたら、あかんのちゃうかな。

・ま、「心配しなくても大丈夫です」って書いてくれてるから、ほんとに表裏が なくて。

・いい子なんはわかるけど、見えすぎ。こういうふうに書いてもらうのは嬉しい。 気にしてくれてんねんな、今新しく調べてんな、昨日一日ですごいユーチューブ とかなんかいろいろ調べて、フェイスブックとかで見て。

・泊めてはあげるけど、これやったら、一緒に来る友達もどんな子を連れて くるんだろうっていう、すごい不安。 


\section{6 評価に著しくばらつきがある学習者 B のメール文}

\section{6.1 B を上位とした評価者のコメント}

学習者 B が書いたメール文に 1 位を付けたのは、NT3である。

(13) N3 の B に対するコメント

・日本語はとても、あまり得意じゃない人が一生懸命、そちらに泊まりたいと 下手な日本語を駆使して頑張っているという感じがあって、「熱中症になら ないように」ってこちらのこともまず聞いてくれているところが、すごい、 いい子だったんだなって。「お父さんも正子もお元気ですか」とか。

・文章も短いのももしかしたら遠慮しがちに、「困ると思ってるならも構い ません」、それでも断られても「家には行きたい、会いたい」とか。すごい 「好き」っていうのが表れてて、ハートウォーミングな感じ。

・日本語が下手な文でも、一生懸命自分のキャパを越えて書いてるぐらい 頑張ってるんじゃないのかなって、愛情を感じる手紙なので。

・都合が悪くても無理やり都合をつけてでも、泊めてあげやんな、かわいそう かなっていう感じがする。

\subsubsection{B を下位とした評価者のコメント}

学習者 B が書いたメール文に NT1 は 4 位を付け、NT2 は 5 位を付けた。

(14) NT1 のB に 対するコメント

・B は、たぶん気持ちはあるんだけど、「お体大切にしてね」、とかあるけど、 なんか「熱中症にならないようにお気をつけてください」、「お元気ですか」、 書いてるんだけど、ちょっと、「だいぶ日常の生活に慣れていて毎日もう充実 に過ごしています」とか、すごく外国人の人の手紙だなという感じで、感じは 悪いことはないし、言いたいことはわかるし、ああ、心配してくれてるんだな、 とは思う。

・本題がすごく短い。文法的におかしいのが続いて、で、最後に、友達と行く から、泊めてもらえないかなっていうので、もうちょっとそこのところは、 丁寧に書いたほうがいい。

・ただ、「もし困ると思っているならも構いませんので」っていうところ、「迷惑 だったらいいですよ」っていうのが書いてあるのは、気持ち自体は全部、この 人は悪くない。 
(15)NT2 の B に対するコメント

・文法はいまいちであっても、「熱中症にならないようにお気をつけてください」 というような、「私に関する気づかいをありがとう」という心の点では、評価 は高い。

・特に不快感はない。

・日本語の点からすると、一番落ちる感じがする。

・一番最後のほうですね、「ぜひお母さんは一晚泊めてもらわないでしょうか? もし困ると思っているならも構いませんので、また冬休みの旅行のときにお宅 に訪れます」って言われると、ま、普通にこの文法を解釈すると、あ、冬休み にまた訪れるんだわ、「訪れていいでしょうか」って聞いてる趣旨と「訪れ ます」っていう意味とがちょっと相反している。

・お父さんと正子のことを気にかけてくれたのは最後の人(B)なので、お父さん と正子は喜ぶと思います。

\section{6. 考察}

\section{1 学習者 A、C、E のメール文の評価にばらつきが少ない理由}

筆者は、メール文の書き方を教える際、基本的に「前置き $\rightarrow$ 本題一結び」の三段階 で構成するように指導している。学習者 A、C、E が書いたメール文は、構成の上 では、習ったことに忠実に従っている。異なる点は、「あいさつ」、「近況報告」「依頼 の理由」に関する情報量である。3 編の中では、情報量が多いほど評価が高いこと がわかる。件名だけは C のほうが A よりよいというコメントがあったが、件名を 除いて本文を見れば、文法や表記の正確さの点でもよい順に A、C、E と言ってよさ そうである。この 3 編のメール文の順位に関しては、筆者を含めた 4 名の日本語 母語話者がほぼ一致している。

\section{2 学習者 Dのメール文の評価がばらつく理由}

学習者 D のメール文も、A、C、E と同じく「前置き $\rightarrow$ 本題 $\rightarrow$ 結びの言葉」の構成と なっている。筆者は、Dには、「まさか…習い始めましたか。」や「遊んでから帰ると 計画しています。」など文法的に正確さに欠ける箇所が少し見られるものの、本題の 依頼に入る前に「近況報告」と「近況伺い」がかなりの字数を使って丁寧になされ、 温かみや親しみが感じられること、また、依頼をした後に「相手の都合が悪い場合 を想定した配慮」もなされていることから、5 編の中で最も高い評価を与えた。NT2 も筆者と近い考えを持っているようである。しかし、Dの情報量の多さについては、 意見が分かれた。NT1 は「メール文としては長すぎる」、『ついでに』が引っかかる」、 NT3 は「キャラが濃い」、「詰め込めるだけ詰め込んで」、「お土産を先に送られると 断りづらい」と感じ、低い評価をしている。筆者は、A は D と比べると情報量が 少なく淡々としていると考えて、Dを 1 位、Aを 2 位とした。しかし、Dのように 情報量が非常に多いと評価者の評価が分かれる原因になる。D に対する筆者と、NT1、 NT3 の意見は異なっている。 


\section{3 学習者 B のメール文の評価がばらつく理由}

筆者は、B については、文法の正確さの面で明らかに他の 4 編より劣ること、 文と文のつながりがしばしばうまくいっていないこと、NT2 も言及していたように、 「お宅に訪れます。」で唐突に終わっていて最後のあいさつもないことなどから、 最も低い評価とした。

日本語教師ではない NT1、NT2、NT3 の 3 名とも、B の日本語力が正確さに欠ける ことには気がついている。しかし、一方で、「熱中症にならないようにお気をつけて ください」、「お父さんも正子もお元気ですか」、「もし困ると思っているならも構い ませんので」という部分に対しては、NT1、NT2、NT3 とも読み手に対する気づかいが あるとして、よい印象があると述べている。

内容的に評価できる部分があっても、NT1 と NT2 の B に対する評価はそれぞれ 4 位と 5 位であるのに対し、特に注目したいのは、Bに 1 位を付けた NT3 のコメント である。「日本語あまり得意じゃない人が一生懸命、下手な日本語を駆使して頑張って いる」、「日本語が下手な文でも、一生懸命自分のキャパを越えて書いてるぐらい 頑張ってるんじゃないのかなって、愛情を感じる手紙」というコメントに表れて いるように、NT3 は、Bの日本語が正確さに欠けることは認めながらも、メールから 一生懸命さや愛情が感じられ、さらには「すごくいい子なんだろうな」とBの人柄 まで想像している。これは次のような理由によるものではないかと考える。初級の 段階では少し話せる（書ける）ようになっただけで、その母語話者から「上手」、 「すごい」とほめられ、上級になると「上手で当然」と見なされてほめられなくなる というのは十分ありえることである。初級や中級の人は、いわば「ハンデ」を 付けて評価されることがあるのではないだろうか。「拙いながらも頑張って話そう

(書こう)」としている態度が「けなげである」と受け止められ、人柄の印象にも 影響を与えうる。B については、筆者と NT2、NT1 の意見は近いが、NT3 とは 大きく異なっている。

以上のことから言えるのは、日本語教師ではない日本語母語話者も、特に日本語 の正確さの面に関しては、似た評価をするということである。そして、上級学習者 は上級だからこそ、「ハンデ」は付けてもらえず、「これぐらい日本語力があるの だから、このような間違った言い方はしないだろう」と期待されることに注意し なければならない。D のメール文の中の「ついでに」の使い方については厳しい 意見があったが、これもまた、Dの日本語力が低くないからこそ「ハンデを付けて もらえなかった」、つまり「見逃してもらえなかった」のではないかと考えられる。 


\section{7. まとめと今後の課題}

以上、本稿では、日本語学習者が書いたメール文を、実際に読み手となる可能 性がある日本語母語話者に評価者として読んでもらい、評価者が付けた順位と コメントを考察した。その結果、個人によって評価にばらつきはあるものの、以下 のような傾向が認められることがわかった。

(1)「前置き $\rightarrow$ 本題 $\rightarrow$ 結び」という構成で、読み手に対する気づかいを感じさせる 言葉や読み手にとって必要な情報を過不足なく含み、日本語としての正確さも あるメール文に対して、日本語母語者（日本語教師も教師でない読み手も）は 高い評価を与える。

（2) 情報量が非常に多い場合は、大きく評価が分かれる。

(3) 日本語の正確さには欠けるが、読み手に対する気づかいを感じさせる言葉を 含んでいる場合、大きく評価が分かれる。

この結果は、日本語教師がメール文の指導をする際、学習者 $\mathrm{A}$ のメール文が多く の日本語母語話者にとって「よい印象を受ける」ものとして、一つのモデル文と なる可能性を示唆している。また、上級日本語学習者に対しては、上級学習者だから こそ、読夕手のハードルが高くなり、たった一つの文法や語彙の運用ミスが全体の 印象を悪くしてしまう恐れがあることもわかった。

しかしながら、今回の調査においては、調査協力者が 3 名と少なかった。今後は、 評価者数を増やした上で、今回と同じような傾向が出るのか確かめる必要がある。 また、宇佐美・森・吉田（2009：132）の「外国人にのみ『日本人に好感をもたれる ように、覀印象を持たれないように』努力を求める、というのは明らかにフェアな ことではない。」という指摘も念頭に置きながら、作文指導のあり方を考えなければ ならないだろう。

\section{参考文献}

上田早苗（2017）「香港の上級日本語学習者が作成した『依頼』のメーループロフィシェンシー の観点から一」第 11 回国際日本語教育・日本研究シンポジウム大会論文集編集委員会編

『日本語教育と日本研究におけるイノベーション及び社会的インパクト』, 52-70 宇佐美洋・森篤嗣・吉田さち（2009）「『外国人が書いた手紙文』に対する日本人評価態度の

多様性一質的手法によるケーススタディ一」『社会言語科学』第 12 巻第 1 号, 122-134 由井紀久子（2005）「書くための日本語教育文法」野田尚史編『コミュニケーションのための

日本語教育文法』くろしお出版, 187-206

\section{引用教材}

野田尚史・森口稔（2003）『日本語を書くトレーニング』ひつじ書房

簗晶子・大木理恵・小松由佳（2005）『これだけ日本語 E-Mai1』衆文図書有限公司 


\section{香港の上級日本語学習者が書いた「依頼」のメールの評価 \\ 一日本語教師ではない読み手の視点一}

\section{〈資料：評価対象となったメール文〉}

※改行位置を「/」で示す。また、メール文は疑似的に作成したものであるが、執筆者個人が 特定できないように、個人名と日付、Eメールアドレスは一部伏せている。

[A] 日付：20XX年 10 月 12 日/発信者：○○/件名：旅行の宿泊について//*田さん//お久し ぶりです。○○です。//去年ホームステイの間、大変お世話になりました。香港に戻って 3 ケ月が経ちまして、今は期末試験やレポートなどの準備をしています。実は、冬休みに 友達と日本一旅行に行くことになりました。その友達は日本の文化や習慣について興味を 持っていて、私のホームステイについての話を聞いたら日本人のおうちを見てみたいと言い ました。もしご迷惑でなければ、私とその友達を一晚泊めていただけないでしょうか。 *田さんのお宅で過ごした生活は大変充実で、一生忘れることがないような素敵な経験だった ので、友達にもホームステイの楽しさを体験してもらいたいです。旅行は 12 月末の一週間 を予定しておりますが、もしその中の一晚泊めていただけたらうれしいです。//お忙しいと は思いますが、お返事をお待ちしております。またお会いできるのを楽しみにしております。

$1 / 00$

[B] お母さんへ//お母さん、お元気ですか? 東京は今一番暑いところなので、熱中症にならない ようにお気をつけてください。お父さんと正子もお元気ですか? 私は香港に戻ってからは もう2 ケ月でした。たいぶ日常の生活に慣れていて、毎日もう充実に過ごしています。今年 の冬休みに友達と日本一旅行に行くことになるんので、その上、友達は日本人のうちを見た ことないから、ぜひお母さんは一晚泊めてもらわないでしょうか?もし困ると思っている ならも構いませんので、また冬休み旅行のときお宅に訪れます。//O○より

[C] 日付：20XX 年 10 月 9 日/発信者：○○/件名：香港からの○○です//お母さん//日本にいる 間お世話になりました。八月無事に香港に戻って、九月に四年生になりました。お母さんの ほうはどうですか。新学期また新しい留学生を受け入れましたか。//実は、お願いしたい ことがあってメールしました。/今年の 12 月 6 日から 12 月 10 日までは冬休みですから、 友達の $\triangle \triangle$ と日本に行くことになりました。香港に戻って、 $\triangle \triangle$ に自分がお母さんのところ での楽しい体験を教えました。 $\triangle \triangle$ も日本に留学したことがありますが、ホームスティー したことはありませんので、日本人のうちを見たことがないらしいです。それで、もし可能

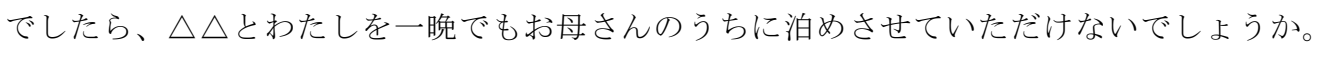
//久しぶりにお目にかかれるのを楽しみにしております。//O○/Email：XXXXXXXXXXX.hk

[D] 日付：20XX 年 10 月 27 日/発信者:XXXXXX@XXXX.com/件名：久しぶりです//お母さん/ ○○です。香港に戻ってからいろいろと忙しくて、連絡が取れなくてすみません。その 代わりに、昨日郵便局で香港のおいしいお土産をたくさん送ったからお許しくださいませ (笑)。ここであらためてお礼を言いたいと思います。去年一年間本当に大変お世話になり 
ました。ありがとうございます。/うちの皆さんはいつものように元気でいますか。そう いえばこの間フェイスブックで $\triangle \triangle$ 君が弓を引いている写真を見ましたけど、まさか $\triangle \triangle$ 君 が弓道を習い始めましたか。もしそうでしたらぜひ教えてほしいものです。/ところで、僕は 冬休みにまた日本に行くことになりました。今度は留学ではなく、友達と東京を六日間堪能 するつもりです。その後二日間関西で遊んでから帰ると計画しています。そこで、関西に いる一日間、お母さんのところへ行き、皆ともう一度会いたいです。ついでにその友達は 日本人の家を見たことがなくてぜひ体験したいと言っていましたから、もし良かったら 12 月の 19 日か 20 日に一晚だけ泊めてもらえませんか。都合が悪ければホテルにします ので遠慮なく言ってください。心配しなくても大丈夫です。/冬休みはまだ二ヶ月ほどですが、 できなかった場合はホテルの予約をしなくてはならないので、1 1 月の中旬ぐらいまでに 泊まり先を決めたいと思います。それまでに返事をいただけるとうれしいです。/またお会い できるのを楽しみにしています。//O○

[E] 日付:20XX 年 10 月 20 日/発信者：○○/件名：泊めるに関するお願い//*谷さんへ//お世話 になっております。○○です。/ホームステイの間、大変お世話になりました。ありがとう ございます。/今日はお願いしたいことがあって、メールをしました。/友達と冬休みに 日本一旅行になりました。友達は日本人のうちを見たことがないと言っています。よろし ければ、一晚泊めてもらえませんか?/ホテルの予約は早めにしたほうがいいので、できねば 11 月 20 日までお返事いただけると助かります。/お返事お待ちしております。/また お会いできるのを楽しみにしております。//O○/EMAIL:XXXXXXXX@XXXX.com 